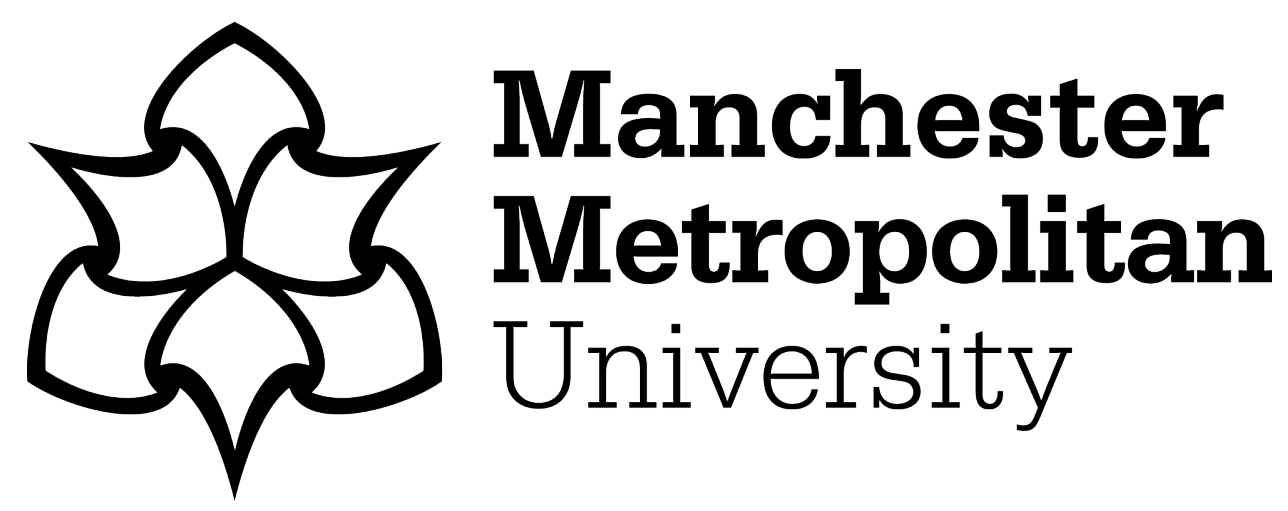

Still, Keith, Papalexi, Marina, Fan, Yiyi and Bamford, David ORCID logoORCID: https://orcid.org/0000-0002-1050-1357 (2020) Place crowd safety, crowd science? Case studies and application. Journal of Place Management and Development, 13 (4). pp. 385-407. ISSN 1753-8335

Downloaded from: https://e-space.mmu.ac.uk/625559/

Version: Published Version

Publisher: Emerald

DOI: https://doi.org/10.1108/JPMD-10-2019-0090

Usage rights: Creative Commons: Attribution 4.0

Please cite the published version 


\title{
Place crowd safety, crowd science? Case studies and application
}

\author{
Keith Still and Marina Papalexi \\ Department of Business, Manchester Metropolitan University - All Saints \\ Campus, Manchester, UK \\ Yiyi Fan \\ Department of Management, Lancaster University, Lancaster, UK, and \\ David Bamford \\ Department of Business, Manchester Metropolitan University - All Saints \\ Campus, Manchester, UK
}

\begin{abstract}
Purpose - This paper aims to explore the development and application of place crowd safety management tools for areas of public assembly and major events, from a practitioner perspective.

Design/methodology/approach - The crowd safety risk assessment model is known as design, information, management-ingress, circulation, egress (DIM-ICE) (Still, 2009) is implemented to optimise crowd safety and potentially throughput. Three contrasting case studies represent examples of some of the world's largest and most challenging crowd safety projects.

Findings - The paper provides some insight into how the DIM-ICE model can be used to aid strategic planning at major events, assess potential crowd risks and to avoid potential crowd safety issues.

Practical implications - It provides further clarity to what effective place management practice is. Evidence-based on the case studies demonstrates that the application of the DIM-ICE model is useful for recognising potential place crowd safety issues and identifying areas for require improvement.

Originality/value - Crowd science is an emerging field of research, which is primarily motivated by place crowd safety issues in congested places; the application and reporting of an evidence-based model (i.e. DIMICE model) add to this. The paper addresses a research gap related to the implementation of analytic tools in characterising place crowd dynamics.
\end{abstract}

Keywords Place crowd safety, Crowd science development

Paper type Case study

\section{Introduction}

Managing crowded places is challenging. Over 100 years ago, in 1902, 25 people died and 517 were injured when the West Stand at Ibrox Park, Glasgow, UK collapsed during an international football match (Still, 2019). In 2019, 16 people died and 101 were injured in a

(C) Keith Still, Marina Papalexi, Yiyi Fan and David Bamford. Published by Emerald Publishing Limited. This article is published under the Creative Commons Attribution (CC BY 4.0) licence. Anyone may reproduce, distribute, translate and create derivative works of this article (for both commercial \& non-commercial purposes), subject to full attribution to the original publication and authors. The full terms of this licence may be seen at http://creativecommons.org/licences/by/4.0/ legalcode

Case studies and application

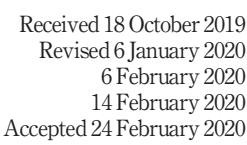

Accepted 24 February 2020

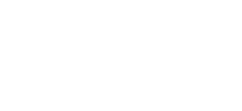


human crush in Antananarivo, Madagascar before a concert at the Mahamasina Municipal Stadium. The show was about to start and people, believing they could enter the stadium, began to push, however, the doors were still closed (Still, 2019). Recently we have global climate strikes on 6 December 2019, with disruptive demonstrations in 2,300 cities across 153 countries (Al Jazeera, 2019). Failures in both place design and place management are not unique and crowd "mis" behaviour is not always the primary cause of accidents and incidents. One common factor is the inappropriate utilisation of space. After major incidents when facts are analysed the crowd is rarely the cause. More commonly the design and management of the place is the problem.

The safety of humans in crowded environments has been recognised as a rapidly growing research area and has been of significant concern to many government agencies (Helbing et al., 2007). Increases in urban populations and mass events have raised interest among researchers and authorities in regard to the problems of pedestrian and crowd dynamics (Haghani and Sarvi, 2018). To date, there has been limited empirical research on pedestrian and crowd behaviours, dynamics and motion (Shahhoseini et al., 2018). Identifying and understanding the mechanisms that may lead to crowd disasters and incidents are critical to ensuring safety in crowded environments (Helbing et al., 2007). In addition to this, place management aims to identify and understand elements such as the political, legal, economic, social and technological aspects of our environment, which ideally lead to ensuring it is "fit for purpose" (Kalandides et al., 2016; Parker, 2008).

This paper reports on the implementation of a crowd safety management tool for places of public assembly and major events and is a practitioner, not a conceptual paper. It provides insight into strategic planning for places regard major events, specifically how to potentially reduce crowd safety issues and as such makes a contribution to the place management and development literature (Badiora and Odufuwa, 2019; Ibem et al., 2013; Kalandides et al., 2016; Parker, 2008; Pasquinelli et al., 2018). The paper addresses a research gap related to the implementation of analytic tools in characterising place crowd dynamics identified by Helbing et al. (2007), the paper provides further clarity in discerning what effective place management practice is, which is important because, as suggested by Kalandides et al. (2016), improved knowledge of this can lead to the development of places that are successful, liveable and equitable. Finally, it can make a defined and measurable impact to place development, not just to specific crowd events but indeed to society as a whole.

This paper will review a selection of the available literature on crowd safety and crowd science in Section 2, followed by Section 3 outlining a crowd assessment safety risk model (the design, information, management-ingress, circulation, egress (DIM-ICE) risk model) used within this paper. Section 4 presents findings then reports on three case studies applying said model and a discussion engages the cases with appropriate literature. Finally, Section 5 describes conclusions and recommendations are made.

\section{Literature review}

\subsection{Crowd dynamics}

A crowd can be defined as follows: "a large group of individuals $(N \geq 100 \mathrm{P})$ within the same space and at the same time whose movements continue for a prolonged period of time $(t \geq 1960 \mathrm{~s})$ dependent on predominantly local interactions $\left(k \geq 1 \mathrm{P} / \mathrm{m}^{2}\right)$ " (Duives et al., 2013, p. 194). It can be seen from this definition that the number $N$ (number of individuals), $k$ (density) and $t$ (time) are the key elements of behaviour (movement/dynamics) of a crowd. However, a crowd is not simply a collection of a number of individuals; rather, it may exhibit highly complex dynamics. 
The dynamics of crowd behaviour and movement depend on various logical crowd-related factors such as average speed, volume and density of the crowd, etc., as well as other psychological and social factors. These dynamics can exhibit a number of unexpected collective phenomena. The most commonly recognised of them discussed in the literature are as follows:

Case studies and application

- lane formation;

- oscillations at bottlenecks;

- the faster-is-slower effect; and

- clogging at exit (Helbing et al., 2000, 2005; Kretz et al., 2006; Georgoudas et al., 2010; Shahhoseini et al., 2018).

High crowd density may result in serious safety issues and crowd disasters. A frequent cause of crowd disasters is overcrowding (Haase et al., 2019). If congestion reaches critical levels, crowd motion transitions into a stop-and-go pattern and eventually causes a phenomenon called crowd turbulence (Helbing et al., 2007). Turbulent crowd motion is characterised by random, unintended displacements of groups in all possible directions (mass motion), which trigger disasters. Large gatherings of pedestrians are found in closed facilities such as shopping malls, stadiums, train stations and in open facilities such as walkways and parks. The number and severity of tragedy crowd disasters in high-density public events have risen significantly in the past decade (Haase et al., 2019). In a recent stampede during Hajj on 24 September 2015, more than 700 people died and more than 850 were injured. Therefore, understanding crowd behaviours and associated risks in high-density environments have the potential to save lives.

\subsection{Crowd risk}

Static crowd density and moving/dynamic crowd density have risks and different limits. Crowd risk level can be determined by integrating crowd density and flow rate as per Figure 1 (Still, 2011). As shown in Figure 1, density is measured by the number of people per $\mathrm{m}^{2}$ and the flow rate is measured per metre per minute. Crowd risk increases with density and flow rate and moves into high risk when the density exceeds a certain point, e.g. five-

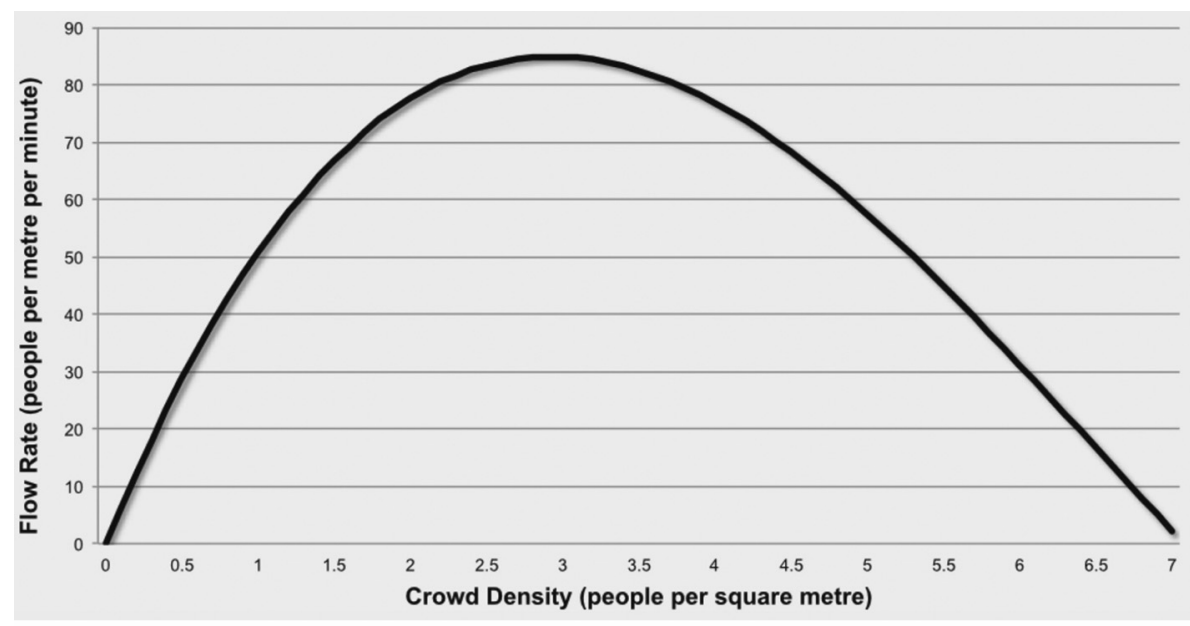

Source: Still (2011)

Figure 1. Crowd density vs crowd flow rate 
person $/ \mathrm{m}^{2}$ suggested by (Still, 2011). Daamen and Hoogendoorn (2003) outline the variance and created a higher flow rate standard in Holland, which was entered into Dutch law. Unfortunately, a "trained crowd" is not like a "tired crowd" leaving a venue or an "uncertain crowd" during an incident. The usefulness of Figure 1 is in defining the language of flow/ density/risk, as the vocabulary is rather vague and the curve is difficult to visualise (without graphics). Using the descriptors free-flowing, capacity and congested provide a clearer definition of the "states" of the crowd flow.

Crowd risk analysis is considered an important aspect of crowd monitoring and management (Smith, 2003). Still (2014a, 2014b) suggests that there are particular issues associated with conventional crowd safety risk assessment documents. He highlighted that as follows:

- these documents are biased towards overestimating risk;

- there is often a "cut and paste" approach to the development of this type of documentation; and most importantly

- there is often a lack of the information required to address relevant crowd safety issues.

Still (2014a, 2014b, p. 48) states that as follows:

the standard crowd risk analysis process of multiplying the likelihood of the risk occurring and the consequences of that risk fails the basic principles of Information Theory (Shannon, 1948) in that it is impossible to reconstruct the conditions that give rise to many crowd related risks, especially those which are dynamic in nature.

Still's (2013) research on crowd disasters found that the design element was the fundamental causality in over half of the incidents and concluded that an appropriate risk analysis of crowds needs to be undertaken to significantly reduce fatalities and serious injuries. This was also identified by Lak et al. (2019) and Ibem et al. (2013), who suggested that appropriate design strategies, which consider participants' preferences, improve the quality of places in different contexts and reduce safety risk. Similarly, Badiora and Odufuwa (2019) highlighted the importance of developing environmental designs for enhancing crowd safety. Fruin (2002) stated that there is a need for adequate formalised training in crowd management principles and techniques, to raise awareness and provide information regarding the appropriate tools that can be applied for an event to be organised successfully avoiding crowd safety risks.

\subsection{Crowd science}

Crowd science is an emerging field of research (Chai et al., 2017), which is primarily motivated by the crowd safety issues in congested environments. Crowd science refers to the study of the effect of density, dynamics and behaviour on a crowd and crowd safety. The concept stems from the initial work of Still (2000) on crowd dynamics, which can be defined as "the study of how and where crowds form and move above the critical density of more

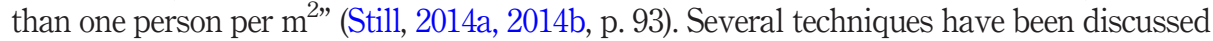
in relation to crowd science in the extant literature as follows:

- crowd modelling;

- crowd counting; and

- crowd monitoring and management (including crowd risk analysis) (Still, 2014a, 2014b). 
Each of these is discussed, in turn, below.

2.3.1 Crowd modelling. Crowd modelling, based on simulating the crowd scenarios under various circumstances, is concerned with building robust representations of a crowd for scene understanding and is primarily a process used in the development of a robust crowd management system. The classical approaches for crowd modelling can be considered under macroscopic and microscopic scales (Xu et al., 2014; Bellomo et al., 2016). Macroscopic models treat the crowd system as a whole and are usually designed to achieve real-time simulation for very large crowds, where each individual's behaviour is not the primary research interest. In contrast, microscopic models are only for smaller crowds to achieve real-time simulation and focus on individual behaviours and their interactions based on complex cognitive models. Various simulation techniques have been developed such as situated cellular agents approach (Bandini et al., 2007). Virtual environment representations have also been constructed for crowd simulations (Yersin et al., 2005; Yersin et al., 2009). A number of behaviour models have been proposed to investigate crowd behaviour (Haghani and Sarvi, 2018) such as flow-based models and agent-based models. Crowd models may also incorporate different facets of a crowd. Some of the work targets the extraneous attributes of a crowd such as poses, movement patterns, appearance and coordinated positions of individuals; and some other work targets how crowds social behaviour emerges over time consequent to external events. However, the descriptive power of such methodologies for practical applications has remained unclear. This has been largely attributed to the lack of evidence-base against, which models can be calibrated or validated. In general, pure mathematical approaches or analytic models are not adequate in characterising crowd dynamics (Helbing et al., 2007).

2.3.2 Crowd counting. Crowd counting is an important task for operational, safety and security purposes. Systems with these functions can be highly effective tools for crowd management (Al-Zaydi et al., 2016). Pedestrian crowd events are common but assessing the safety of such events has proven difficult. According to Duives et al. (2013), not only are the layouts of the infrastructure different but also movements of pedestrians differ significantly between events. Different non-visual and visual methods are used for crowd counting and include various methods such as tally counters (Lev et al., 2008), differential weight counters (dos Reis, 2014), infrared beams, wireless fidelity network and wireless sensor network based counters (Yuan et al., 2011; Di Domenico et al., 2016). Visual-based crowd counting systems can be deployed using different types of cameras. According to Al-Zaydi et al. (2016), methods based on computer vision are one of the best choices because cameras have become ubiquitous and their use increasing. There are an estimated six million CCTV cameras installed in the UK (Birch et al., 2017). In comparison with computer vision-based methodology, other non-visual methods need to be carefully planned and deployed for specific purposes and the accuracy is often less than a computer vision-based technology. Crowd counting based on computer vision can be classified into a line of interest and region of interest (Li et al., 2011). Research into people counting in sparse environments is well established, but there are still many challenges and limitations to overcome in crowded environments (Hou and Pang, 2010). They report on a lack of knowledge of how to handle occlusion (obstructions/blockages), which may only slightly affect crowd counting in sparse environments, but its effect increases significantly in crowded environments. Therefore, there is a need to develop a method to measure the level of occlusion, thereby improving the accuracy of counting. Experience demonstrates that event organisers typically inflate (grossly) their proposed numbers and the authorities then mobilise what they consider to be a proportionate response. The authorities turn out in force (expecting a larger crowd) and are seen as having provided a disproportionate response. 
2.3.3 Crowd monitoring and management (including crowd risk analysis). Crowd monitoring deals with constructing systems for real-time decision support through the statistical analysis of visual data. Furthermore, crowd management deals with the strategic, tactical and operational handling of crowds ensuring safety in an uncompromising yet efficient manner. Crowd risk analysis is considered to be an important aspect of crowd monitoring and management (Smith, 2003). A number of studies highlight the shortcomings of the traditional approach for assessing risks at mass gatherings. First, a traditional risk assessment approach is insufficient to predict human behaviour (Upton, 2004). Second, conventional risk assessment methods are biased towards overestimating risk (Still, 2019). Despite the importance of the dynamic nature of crowd-related risks, the extant literature has not progressed the notion of monitoring, assessing or describing crowds to underpin interventions or controls. Also, there is limited evidence of practical applications for dynamic crowd risk analysis and monitoring.

\subsection{The limits of current knowledge in the field}

Fruin (1984) and Sime (1993) highlighted that there is a need to understand the interaction of efficient crowd management and place systems design for events, as these are the major factors that affect crowd disasters. Berlonghi (1995) argued that mismanagement of crowd risk may result in serious losses of life, health, property and money. Some operational guidelines and legislation are available (although crowd safety legislation and guidance are different across the UK, Europe, USA and Australia), which highlight measures that should be adopted in the context of crowd risk management regard the success of the delivery of events. For example, the "Green Guide", in Guide to Safety at Sports Grounds (Health and Safety Executive [HSE], 1997; GSSG, 2008), the "Primrose Guide" in Guide to Fire Precautions in Existing Places of Entertainment and Like Premises (Health and Safety Executive [HSE], 1998) and the "Purple Guide" in Event Safety Guide (Health and Safety Executive [HSE], 1999). The Safety at Sports Grounds 2018 Edition (Version 6) and the Primrose Guides (fire safety was replaced with a series of guides specific to premises) were replaced by the UK Building. The Purple Guide has also been extensively rewritten but is now subscription only.

However, there is still evidence that reveals clearly insufficient and inadequate planning at high-density public events (Haase et al., 2019; Shahhoseini et al., 2018). Perhaps, these guidelines do not go far enough; the Fire codes set the times for evacuation, but this is based on the assumption of, namely, instant reaction to alarms; and the fire is no longer the only threat. We now have chemical, biological, radiological and nuclear threats, active shooter, etc. This means that the assumption of egress routes and viability, types of alarm, nature and direction of a threat, etc are all new variables and not the same as the "fire" assumptions.

\section{Research methodology}

Our study aims to provide empirical evidence of using relevant techniques for dynamic risk analysis to understand how to improve place crowd safety and throughput. To achieve this objective, the paper adopts a multiple case study approach (Yin, 2018). However, gaining access to organisations and having permission to share the outcomes for this type of research can be difficult and is granted through a combination of good luck, effective planning and hard work (Bell et al., 2018). The paper has, therefore, presented a summary of projects that the lead author engaged with over time. The modelling tool presented in Table 1, the "DIM-ICE risk model" was developed by Still (2009) from the application of evidence-based mathematical formulae and direct interactions with clients over an extended period. Primary data were collected based on the lead author's experiences in these interactions. The case studies reported in the findings section, chosen to be representative of 


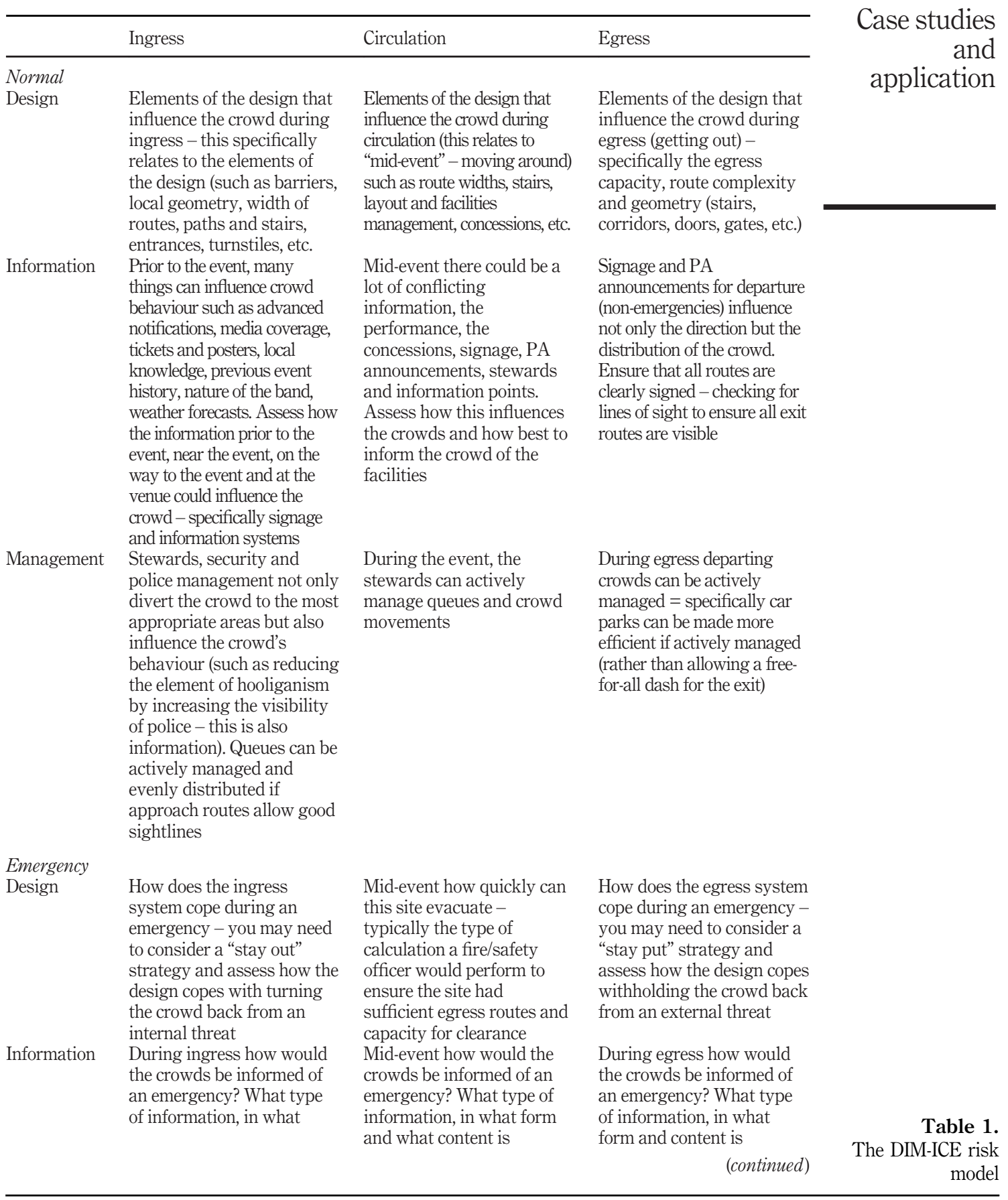


JPMD

\begin{tabular}{lll}
\hline Ingress & Circulation & Egress \\
\hline $\begin{array}{ll}\text { form and content is } \\
\text { required? }\end{array}$ & $\begin{array}{l}\text { required? Ensuring the } \\
\text { crowd moves away from } \\
\text { the threat requires more }\end{array}$ & $\begin{array}{l}\text { required? For this, you need } \\
\text { to consider the crowd in the } \\
\text { process of normal egress }\end{array}$
\end{tabular}

Management During ingress, there may be more people trying to gain entry than is physically possible (for example, a "free" event). The crowds may need active management to prevent overcrowding in the event space. This would be considered an emergency situation as there is a risk of crushing if the event does not have an active management system the threat requires more than just a please leave an announcement

During the event, the crowd may need to be managed (directed) away from a threat. Consider the information (above) and the management of the egress for a direction that ensures the crowd moves as quickly as possible away from the source of danger
The crowd may need to be managed after vacuation (say on a holding area) to be kept safe until the threat/

danger has passed You may need to keep managing the crowd for several hours during a holding operation. You will need to keep the crowd informed until it is safe to let the crowd disperse

Table 1.

Source: Still, 2009

the scope and scale of place management within the word limits of a journal paper, contribute to the evidence base on the adoption and adaptation of place crowd safety and crowd science "best practice" within organisations.

This "DIM-ICE risk model" can be used to identify the multiple and complex issues associated with crowd safety by taking into account the density, behaviour and dynamics of crowds (Still, 2009). Still's DIM-ICE risk model considers three fundamental categories of systemic failure that are applicable to all crowd-related incidents, these are:

(1) design;

(2) information; and

(3) management-related failures.

The DIM-ICE risk model assesses these categories against three identified phases of crowd movement in high-density environments, namely:

(1) ingress (arrival);

(2) circulation (movement within the venue); and

(3) egress (departure).

The model combines these elements into a matrix framework (Table 1). It is important to present this here to provide sufficient detail regards the different elements involved and to provide some contextualisation for the application of theory in the cases.

Table 2 presents the Crowd Safety Projects from 1999 to 2019 and provides a useful overview of the scope and scale of application of the techniques discussed in the paper. Importantly, it provides the evidence of the application of the DIM-ICE risk model to 68 projects and, when the singular public interactions per site (post-intervention) are counted, 


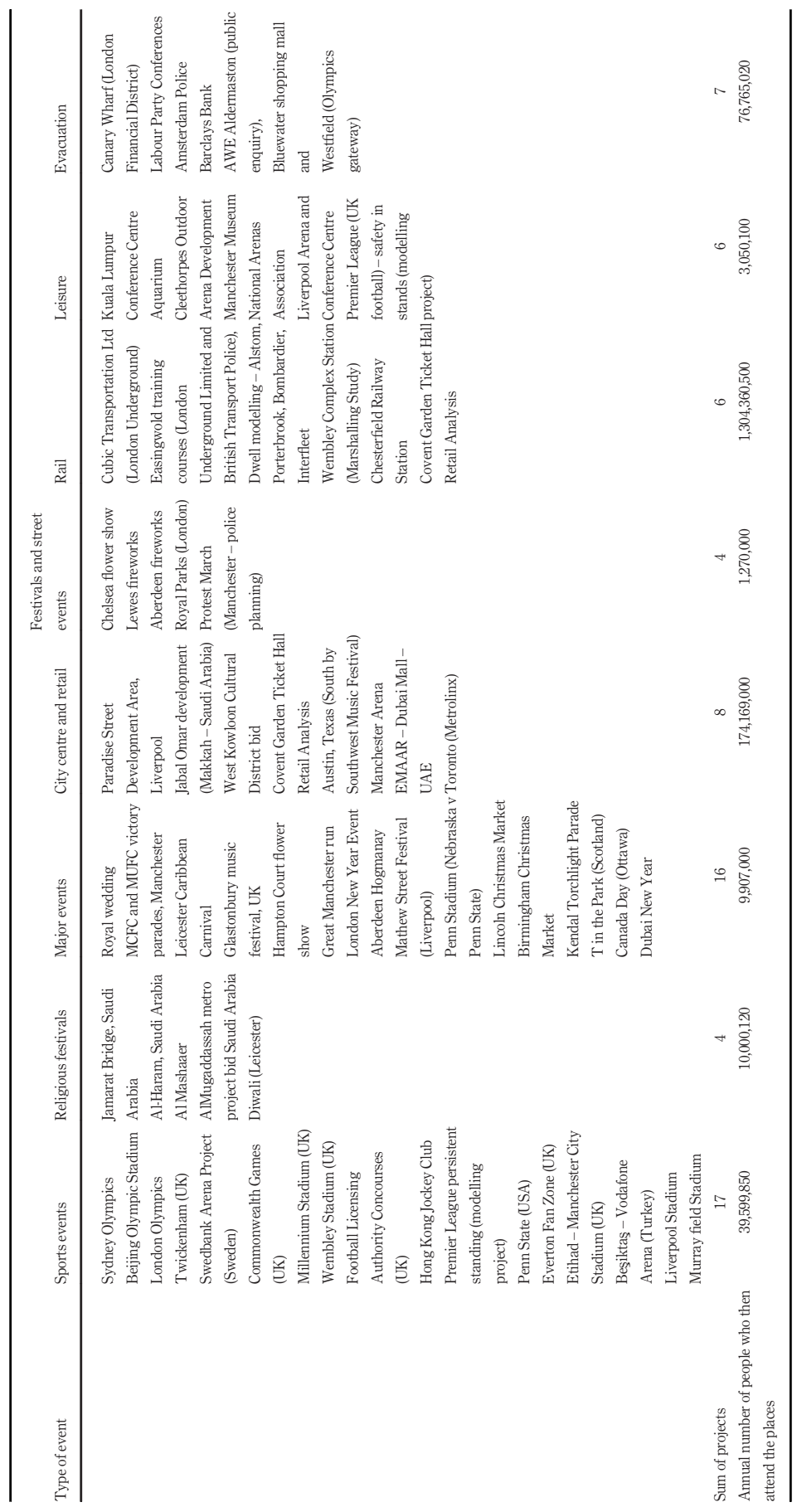

Case studies application

Table 2. Crowd safety projects from 1999 to 2019 
this equates to a total overall annual impact on 1,619,121,590 individuals who subsequently attended the venues.

Interestingly, presenting the data from Table 2 in a slightly different manner demonstrates that the projects split into three main groups (Figure 2), according to the level of crowd density in the crowd safety projects from 1999 to 2019. Figure 2 shows the small, medium and large scale application of the DIM-ICE risk model across a number of representative places (e.g. religious festivals in the far east, multiple Olympic games, mass transit, etc.) characterised by crowd density. The following section reports on the actual application of the model at three large and challenging crowd safety projects as follows:

(1) Sydney Olympics project;

(2) Canary Wharf project;

(3) Murrayfield Stadium project.

The case studies report on the use of the DIM-ICE risk model. The rationale of choosing these three projects was guided by our main research objective, to report on the implementation of an analytic tool in characterising place crowd dynamics. As discussed in the literature, there is a lack of clarity on the descriptive power of such methodologies for practical applications. Choosing three cases also provides us with opportunities to both expand this evidence base and to validate the DIM-ICE model.

The DIM-ICE risk model is a technique, which acts as a predictor of crowd activity and behaviour; it identifies the principles that we should be looking for to prevent future incidents. It assists in understanding the routes of crowds and highlights areas and times of high risk, which enable to organisers to deal with those risks and control them through effective design, information systems and management strategies. Initially, the DIM-ICE model is a blank template. By thinking through the details that need to go in each box, we encourage a structure to both the risk analysis and understanding of the causes of accidents and incidents. The next phase of the process is to categorise the elements of the DIM-ICE model into three identified group, namely:

(1) things that go well;

(2) things that need to be monitored; and

(3) things that require improvement.

Figure 2.

Crowd density and crowd safety projects taken place from 1999 to 2019

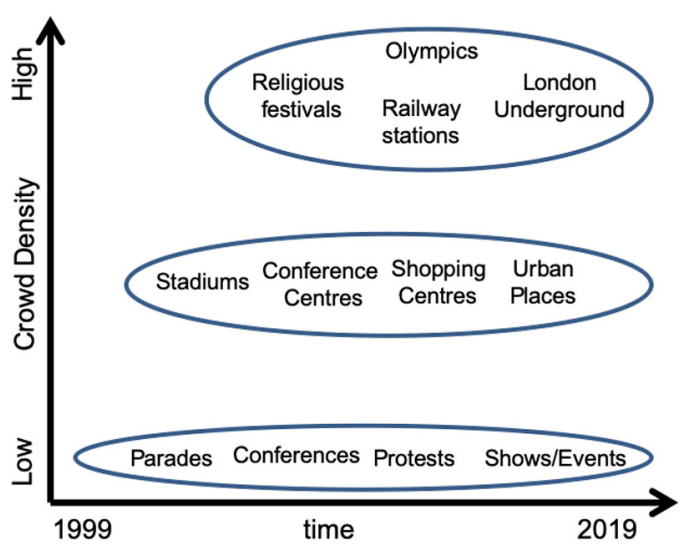


The DIM-ICE risk model also assisted in creating a one-way system to optimise crowd movement by using Network analysis theory (Still, 2019). This one-way system included all possible options available to the attendees and introduced additional nodes. As part of it, a command and control tool was designed, which was an excel spreadsheet where information such as events start times, transit times, transit capacity, queuing times for security and screening, walk time to get to the stadium and the seating time, were all included. This approach assisted in identifying the number of people that would be in circulation (people moving between events) rather than in the stadiums. It provided an estimation of the expected number of pedestrians moving around the common domain. The method provided information to patrons that enabled them to manage their schedule to arrive at the stadium on time without experiencing unpleasant incidents such as long waiting times or an accident.

\section{Findings}

This section presents the findings from the application of the DIM-ICE risk model as Case 1, Case 2 and Case 3, respectively, in chronological order (from 2000 to 2018) to showcase the use of this model. Each of these cases outlines the context and impact of application; however, please note that some of the exact detail (especially regarding metrics and operational elements) have understandably had to be withheld for reasons of security.

\subsection{Case 1 - Sydney Olympics project (2000)}

The 24th Olympic games were held in September 2000 in Sydney, New South Wales, Australia. Approximately 11,000 athletes participated in the games and a total of 6.7 million games tickets were sold (92.4 per cent of the availability). Before the Sydney 2000 Games started, the organisers realised that they had to deal with a significant challenge as follows: how to design optimal throughput, minimise the exposure to crowd safety risk and provide a successful and pleasant event. Crucially, they had to deal with non-event ticketing spectators (people that just wanted to be part of the Olympics atmosphere). Although they knew the capacity of the domain, they could not estimate the number of non-event ticketing spectators attending the games. Therefore, they requested external advice on how to face this issue because they did not have the knowledge and skills in-house. Table 3 presents a summary of the Sydney Olympic Games project.

The DIM-ICE risk model was applied to the circulation and movement of the people attending the event(s). The implementation of the model aimed to identify areas that required improvement (e.g. expected high-density) and reduce the risk of crowd safetyrelated issues. Figure 3 presents the DIM-ICE risk model created for the Sydney Olympics project. Specifically, as Figure 3 summarises, during normal conditions, the main challenges that the model identified were as follows:

- Design category: difficulties in estimating the number of non-event ticketing spectators, which caused a risk of overcrowding during the ingress, circulation and egress phases.

- Management category: difficulties in managing peoples' movements, especially from North-South in the event area during the ingress and circulation phases.

Under an emergency condition, the DIM-ICE risk model assisted in realising that there were a number of potential crowd safety-related issues that the organisers had to address to offer a safe environment.

Case studies
and
application

$-$




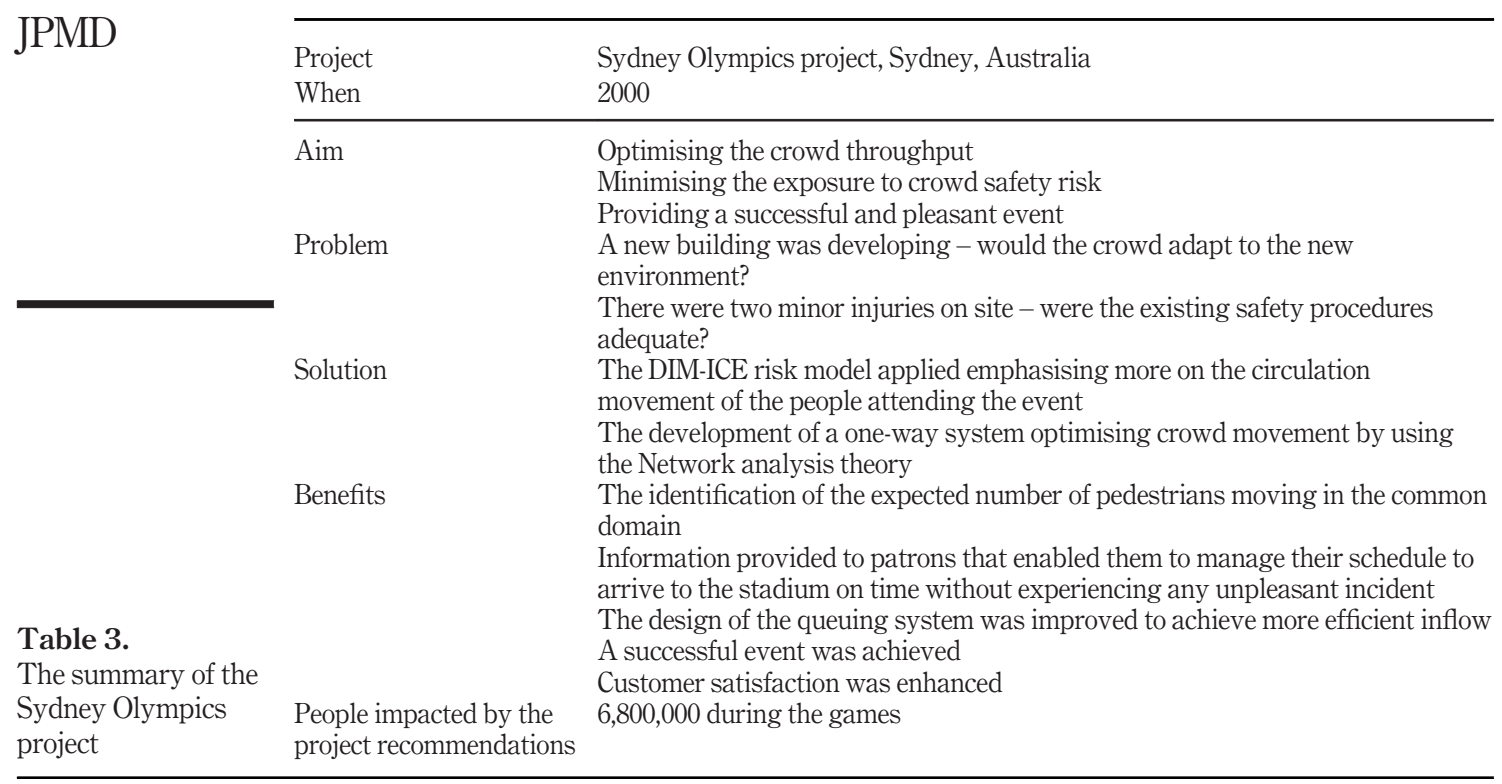

- Design category: during the circulation phase, there was a limited flow capacity. Considering that the number of non-event ticketing spectators could not be estimated, this may have caused difficulties in attendees' movements and safety issues.

- Information category: there was unclear signage during the circulation and egress phases.

- Management category: the model identified that a detailed evacuation plan was missing, another potential crowd safety issue.

The data analysis revealed that, approximately, it would take at least $2 \mathrm{~h}$ to get from places like Sydney into the seating area. However, the attendees were informed, by the organisers of the Sydney 2000 Games that it would take $4 \mathrm{~h}$ to arrive at the venue. The reason, to avoid crowd safety-related issues and provide a greater distribution of people's arrival times. Patrons were satisfied because there was a variety of events/entertainment in the concessions around the stadiums in the common domain spaces; plus, they arrived in the venue on time/in plenty of time (under promise and over deliver).

Based on the data analysis, an estimation regarding the demand at the maximum point of the system was achieved. In total, 80,000 people per hour was the full capacity of the system this was calculated by optimising routes, making them wide enough (e.g. $20 \mathrm{~m}$ wide to facilitate a flow rate of 82 people per metre per minute), etc. As a result, the DIM-ICE risk model helped to designed resilience into the system and ensured that the peak demand represented 80 per cent of the system's capacity consistently allowing greater efficiency.

\subsection{Case 2-Canary Wharf project (2003)}

In the early 2000s Canary Wharf in London, UK (a major finance hub) experienced at least two "bomb threats" per week (Mullin et al., 1996). Reports of vehicles laden with explosives or the existence of so-called "parcels bombs" in particular places were a regular occurrence. 


\begin{tabular}{|c|c|c|c|}
\hline NORMAL & Ingress & Circulation & Egress \\
\hline \multirow{3}{*}{ Design } & $\begin{array}{l}\text { The capacity of the } \\
\text { domain is known; } \\
\text { Limited flow capacity } \\
\text { (narrow footpaths- } 7 \mathrm{~m} \\
\text { entry) }\end{array}$ & $\begin{array}{l}\text { Wide event area, } 4 \\
\text { video screens to draw } \\
\text { people away from } \\
\text { official area. }\end{array}$ & $\begin{array}{l}\text { Limited flow capacity } \\
\text { (narrow footpaths) }\end{array}$ \\
\hline & $\begin{array}{l}\text { Limited entry capacity: } \\
\text { queuing/congestion }\end{array}$ & $\begin{array}{l}\text { Overcrowding; } \\
\text { pedestrians moving } \\
\text { around the common } \\
\text { domain }\end{array}$ & $\begin{array}{l}\text { Limited exit capacity; } \\
7 \mathrm{~m} \text { roadway blocked } \\
\text { to allow people to } \\
\text { egress safely. }\end{array}$ \\
\hline & $\begin{array}{l}\text { The number of non- } \\
\text { event ticketing } \\
\text { spectators cannot be } \\
\text { estimated }\end{array}$ & $\begin{array}{l}\text { Risk of crowd safety } \\
\text { related issues: the } \\
\text { number of non-event } \\
\text { ticketing spectators } \\
\text { cannot be estimated }\end{array}$ & $\begin{array}{l}\text { Risk of crowd safety } \\
\text { related issues: e.g. } \\
\text { congestion at exits } \\
\text { areas and emergency } \\
\text { exit areas }\end{array}$ \\
\hline Information & $\begin{array}{l}\text { Information on arrival } \\
\text { times are required to } \\
\text { avoid crowd safety } \\
\text { related issues; RSL } \\
\text { website to be used to } \\
\text { educate patrons } \\
\text { commence recently. }\end{array}$ & $\begin{array}{l}\text { Unclear signage for } \\
\text { pedestrians moving } \\
\text { around the common } \\
\text { domain }\end{array}$ & $\begin{array}{l}\text { Signage and usher } \\
\text { support on egress. } \\
\text { RSL website } \\
\text { education provided. }\end{array}$ \\
\hline \multirow[b]{2}{*}{ Management } & $\begin{array}{l}\text { Non-event ticketing } \\
\text { spectators; visitors are } \\
\text { not counted - risk for } \\
\text { overcrowding }\end{array}$ & \multirow{2}{*}{$\begin{array}{l}\text { Challenges to move } \\
\text { people around venue } \\
\text { due to environment. } \\
\text { Difficulty to move } \\
\text { from North-South in } \\
\text { event area. }\end{array}$} & \multirow{2}{*}{$\begin{array}{l}\text { Sudden movement } \\
\text { post event, police } \\
\text { direction, security, } \\
\text { traffic controllers and } \\
\text { transport hub } \\
\text { personnel. }\end{array}$} \\
\hline & $\begin{array}{l}\text { Traffic Management } \\
\text { Plan implemented. } \\
\text { Road closures. Signage } \\
\text { and volunteers to } \\
\text { guide. }\end{array}$ & & \\
\hline \multicolumn{2}{|l|}{ EMERGENCY } & Circulation & Egress \\
\hline Design & $\begin{array}{l}\text { Emergency service on } \\
\text { site. Access to } \\
\text { additional emergency } \\
\text { vehicles. Ambulance } \\
\text { and first aid teams } \\
\text { positioned around area. }\end{array}$ & $\begin{array}{l}\text { Limited flow capacity } \\
\text { Risk of crowd safety } \\
\text { related issues: the } \\
\text { number of non-event } \\
\text { ticketing spectators } \\
\text { cannot be estimated }\end{array}$ & $\begin{array}{l}\text { Additional emergency } \\
\text { egress routes available }\end{array}$ \\
\hline Information & $\begin{array}{l}\text { Information on arrival } \\
\text { times are required to } \\
\text { avoid crowd safety } \\
\text { related issues }\end{array}$ & $\begin{array}{l}\text { Signage difficult due } \\
\text { to venue design. }\end{array}$ & $\begin{array}{l}\text { Escape routes are not } \\
\text { clearly marked } \\
\text { (signage/lights) }\end{array}$ \\
\hline Management & $\begin{array}{l}\text { A detailed evacuation } \\
\text { plan is missing }\end{array}$ & $\begin{array}{l}\text { A detailed evacuation } \\
\text { plan is missing }\end{array}$ & $\begin{array}{l}\text { A detailed evacuation } \\
\text { plan is missing }\end{array}$ \\
\hline
\end{tabular}

Notes: White squares $=$ areas that are sufficient, no improvements are required; Light grey squares $=$ require improvement; and Grey squares $=$ require much improvement to avoid crowd safety issues

Figure 3. The DIM-ICE risk model - the Sydney

The UK's London Metropolitan Police Service was facing complications in dealing with these issues because it did not have an official or legal authority to call for an evacuation of areas or premises unless there was an imminent risk to life (there are both legal and financial restrictions to evacuating a major banking centre due to the high number of false alarms). The Metropolitan Police Service could not force an evacuation because of the potential for false alarms and there was no system in place to quantify the level of threat. Therefore, it was decided that a top-down command and control evidenced-based procedure was required for any building to be evacuated; this was serving the dual purpose of protecting lives and minimising the potential risk of litigation.

The unique positioning of Canary Wharf London is complicated because it is an island surrounded by water, it, therefore, has limited exit points and emergency access routes. The 
challenge of providing directional information (i.e. which was the safe way to go) to people to move away from the potential threats become complex. Table 4 provides an overview of the Canary Wharf project.

Applying the DIM-ICE risk model, a transparent and robust network analysis was conducted. This served to analyse the capacity of available roads and optimised the crowd moved away from the location of the threat. Figure 4 presents the DIM-ICE risk model applied for the Canary Wharf project. The areas that required further improvements for any potential crowd safety issues to be avoided were identified. As Figure 4 summarises, under normal conditions, the main challenges were as follows:

- Design category: the limited capacity of available roads, which could cause serious safety issues as there were difficulties in directing people to move away from potential threats during the ingress, circulation and egress phases.

- Management category: the Metropolitan Police Service was facing difficulties in managing information regarding the capacity and availability of routes during the ingress phase.

- Under emergency conditions, the DIM-ICE risk model identified similar potential crowd safety-related issues.

- Design category: the limited capacity of available roads negatively impacted the design of an optimum route to keep people away from potential threats.

- Information category: a significant issue was the lack of information to identify the severity of the threat and on routes that had the maximum capacity to direct people to move away from potential threats.

- Management category: the model identified the need for a detailed evacuation plan, to help the Metropolitan Police Service follow standardised procedures, avoiding potential issues related to crowd safety.

Based on the DIM-ICE risk model, bespoke software was developed by the London Metropolitan Police Service for Canary Wharf, representing the entire site using coordinated grids. The location of any potential threat was indicated by a specific grid reference and the severity of the threat identified by a physical radius. The algorithms within the software

\begin{tabular}{ll}
\hline Project & Canary Wharf project, London, UK \\
\hline When & $\begin{array}{l}\text { 2003 } \\
\text { Optimising the crowd throughput } \\
\text { Canary Wharf was experienced an incredible crowd safety restated tread } \\
\text { and the police did not have the official or legal authority to call an } \\
\text { evacuation } \\
\text { Problem }\end{array}$ \\
$\begin{array}{l}\text { The use of DIM-ICE risk model assisted in analysing the capacity of all } \\
\text { the existing available roads and optimising the crowd movement away } \\
\text { from the location of the thread }\end{array}$ \\
$\begin{array}{l}\text { Information provided regarding the route that had the maximum } \\
\text { capacity to direct people and move them away from the thread } \\
\text { Benefits }\end{array}$
\end{tabular}

The summary of the Canary Wharf

Notes: White squares = areas that are sufficient, no improvements are required; light grey squares = project require improvement; and grey squares = require much improvement to avoid crowd safety issues. 


\begin{tabular}{|c|c|c|c|}
\hline NORMAL & Ingress & Circulation & Egress \\
\hline \multirow{2}{*}{ Design } & $\begin{array}{l}\text { Limited capacity of } \\
\text { available roads }\end{array}$ & \multirow{2}{*}{$\begin{array}{l}\text { Difficulties in } \\
\text { directing people to } \\
\text { move away from the } \\
\text { potential threats }\end{array}$} & \multirow{2}{*}{$\begin{array}{l}\text { Limited exit points } \\
\text { and emergency } \\
\text { access routes }\end{array}$} \\
\hline & $\begin{array}{l}\text { Limited emergency } \\
\text { access routes }\end{array}$ & & \\
\hline Information & $\begin{array}{l}\text { Lack of information } \\
\text { on identifying the } \\
\text { severity of the threat }\end{array}$ & $\begin{array}{l}\text { Lack of signage } \\
\text { for people to move } \\
\text { away from the } \\
\text { potential threats }\end{array}$ & $\begin{array}{l}\text { Lack of information } \\
\text { on routes that had } \\
\text { the maximum } \\
\text { capacity to direct } \\
\text { people to move from } \\
\text { the potential threats }\end{array}$ \\
\hline \multirow{3}{*}{ Management } & $\begin{array}{l}\text { Managing } \\
\text { information } \\
\text { regarding capacity } \\
\text { and availability of } \\
\text { routes }\end{array}$ & \multirow{2}{*}{$\begin{array}{l}\text { No } \\
\text { queuing/congestion } \\
\text { management }\end{array}$} & \multirow{2}{*}{$\begin{array}{l}\text { No } \\
\text { queuing/congestion } \\
\text { management }\end{array}$} \\
\hline & $\begin{array}{l}\text { No } \\
\text { queuing/congestion } \\
\text { management }\end{array}$ & & \\
\hline & $\begin{array}{l}\text { Lack of training } \\
\text { programme and } \\
\text { situation awareness } \\
\text { for all levels of } \\
\text { command and } \\
\text { control for the site }\end{array}$ & $\begin{array}{l}\text { Lack of training } \\
\text { programme and } \\
\text { situation awareness } \\
\text { for all levels of } \\
\text { command and } \\
\text { control for the site }\end{array}$ & $\begin{array}{l}\text { Lack of training } \\
\text { programme and } \\
\text { situation awareness } \\
\text { for all levels of } \\
\text { command and } \\
\text { control for the site }\end{array}$ \\
\hline
\end{tabular}

\section{Case studies and application}

\begin{tabular}{|l|l|l|l|}
\hline & \multicolumn{1}{|c}{ Ingress } & \multicolumn{1}{c}{ Circulation } \\
\hline Design & $\begin{array}{l}\text { Limited emergency } \\
\text { access routes }\end{array}$ & $\begin{array}{l}\text { Difficulties in } \\
\text { directing people to } \\
\text { move away from the } \\
\text { potential threats }\end{array}$ & $\begin{array}{l}\text { Limited exit points } \\
\text { and emergency } \\
\text { access routes }\end{array}$ \\
\hline Information & $\begin{array}{l}\text { Lack of information } \\
\text { on identifying the } \\
\text { severity of the threat }\end{array}$ & $\begin{array}{l}\text { Lack of signage } \\
\text { for people to move } \\
\text { away from the } \\
\text { potential threats }\end{array}$ & $\begin{array}{l}\text { Lack of information } \\
\text { on routes that had } \\
\text { the maximum } \\
\text { capacity to direct } \\
\text { people to move from } \\
\text { the potential threats }\end{array}$ \\
\hline Management & $\begin{array}{l}\text { A detailed } \\
\text { evacuation plan is } \\
\text { missing }\end{array}$ & $\begin{array}{l}\text { A detailed } \\
\text { evacuation plan is } \\
\text { missing }\end{array}$ & $\begin{array}{l}\text { A detailed } \\
\text { evacuation plan is } \\
\text { missing }\end{array}$ \\
\hline
\end{tabular}

Notes: White squares $=$ areas that are sufficient, no improvements are required; light grey squares $=$ require improvement; and grey squares $=$ require much improvement to avoid crowd safety issues. White squares $=$ areas that are sufficient, no improvements are required; light grey squares = equire improvement; and grey squares = require much improvement to avoid crowd safety issues

Figure 4. The DIM-ICE risk model - the Canary Wharf project

provided the information required to identify routes that had the maximum capacity to direct people and move them away as safely as possible. A complicating factor was that the accessibility of routes was constantly changing (building works, repairs, road layout changes, etc.), which affected the capacity of specific routes. Therefore, the software required constant updating and development for significant information regarding the capacity and availability of routes to be as robust and accurate as possible. The use of the DIM-ICE risk model provided the much-needed evidence-based solution to a highly complex and changeable problem area. 
The project had three core modelling element, a generic routing diagram (as a lookup table) and a specific threat location exclusion network (only showing viable routes depending on location and severity of the threat). This was coupled to information-based maps and video clips for training the occupants and a "pied piper approach" to egress. That is, instead of pushing people out of buildings, marshals were trained to lead people away from the threat. The instructions for the occupants were to "follow the crowd and keep going”. In essence, this meant there developed a directional approach to all possible threat locations. This was coupled to a training programme and situation awareness for all levels of command and control for the site.

\subsection{Case 3 - Murrayfield stadium project (2018)}

Murrayfield Stadium is a sports stadium located west of Edinburgh, the capital of Scotland. It is the largest and most impressive stadium in Scotland and the fifth largest in the UK with a seated capacity of 67,144. It is the home of Scottish rugby and Murrayfield Stadium has also hosts musical events.

In November 2018, expert advice on crowd safety was required for two reasons as follows: a new building was to be developed, close to the site, which would impact upon the layout of the merchandising area both during and after its construction. The physical change to the site were known, but the impact during construction and on the merchandising locations post-build were under negotiation. An investigation into how the crowd was going to adapt to the new environment was required; there were two minor injuries on-site, which made the operations team of the Murrayfield stadium seek advice on whether existing crowd safety procedures were sufficient from both a health and safety perspective and potential exposure to litigation. The use of the DIM-ICE risk model assisted in analysing the current situation and providing a set of recommendations. Table 5 summarises the Murrayfield Stadium project.

To develop the DIM-ICE risk model, data was collected through conducting a site survey (a day on the site as a customer - walking to various areas, setting up cameras, extensive videoing of ingress, circulation and egress); using the data from the stadium CCTV cameras

\begin{tabular}{|c|c|}
\hline Project & Murrayfield Stadium, Edinburgh, UK \\
\hline When & 2018 \\
\hline Aim & Optimising the crowd throughput \\
\hline \multirow[t]{2}{*}{ Problem } & $\begin{array}{l}\text { A new building was developing - would the crowd adapt to the new } \\
\text { environment? }\end{array}$ \\
\hline & $\begin{array}{l}\text { There were two minor injuries on site - were the existing safety } \\
\text { procedures adequate? }\end{array}$ \\
\hline Solution & $\begin{array}{l}\text { The use of DIM-ICE risk model assisted in analysing the current situation } \\
\text { and providing a set of recommendation }\end{array}$ \\
\hline \multirow[t]{4}{*}{ Benefits } & $\begin{array}{l}>90 \% \text { of Murrayfield Stadium's safety operations were appropriate } \\
\text { Areas that required improvement regarding the existing risk assessment } \\
\text { policy were identified }\end{array}$ \\
\hline & $\begin{array}{l}\text { The design of the queuing system was improved to achieve the more } \\
\text { efficient inflow }\end{array}$ \\
\hline & $\begin{array}{l}\text { Murrayfield Stadium demonstrate continual assessment and } \\
\text { improvement to the risk management process }\end{array}$ \\
\hline & Customer satisfaction was enhanced \\
\hline $\begin{array}{l}\text { People impacted by the project } \\
\text { recommendations }\end{array}$ & 67,000 per event \\
\hline
\end{tabular}

Table 5.

The summary of the Murrayfield Stadium project 
and also reviewing the existing risk assessment policies. Based on the data analysis, the DIM-ICE matrix was created, which highlighted areas that required improvements. Figure 5 presents the DIM-ICE risk model applied to the Murrayfield Stadium project. More than 90 per cent of Murrayfield Stadium's safety operations were well above the standards appropriate for stadia of this size, but there were critical elements that required review. Areas that required improvement were identified and the design of the queuing system improved to achieve more efficient inflow. The analysis of the data demonstrated that there was a significant risk on the site - a narrow area at the west end of the stadium with the rather high-density flow (as a result merchandising in this area was highly profitable). There were also waste bins in that area, which further reduced the width. Specifically, as Figure 5 summarises, the main areas that required involvements were related to the existence of an emergency situation as follows:

- Design category: the identified narrow area could cause overcrowding at the ingress, circulation and egress phases.

- Information category: visitors might have difficulties in exiting the stadium due to unclear signage, which could cause safety issues.

- Management category: the model identified that the risk assessment processes had to be updated, which was a critical requirement for creating a safe environment.

In addition, the development of the new building, by changing dynamics of flow, changed the routing and footfall moving in and out the stadium, specifically if an emergency situation required a directional egress close to the construction site during the build. A number of recommendations were made, aiming to provide solutions to the identified safety issues. Initially, the operations team were recommended to: update the risk assessment processes, to increase the width of the west end area with the tight footfall (density); and to move the waste bins units out of the high footfall (volume) area, which would reduce the flow constraint to make it more efficient and accessible for patrons. Finally, an engagement between the operations team and the building construction engineers was recommended to ensure that specific corridors would remain clear and available for the crowd, during the construction phase. Note: one of the modelling tools used here was the risk/congestion mapping, a visual approach to identifying areas of high footfall and potential congestion at specific times during an event (ingress/circulation/egress).

\section{Discussion and final remarks}

To add value to the discussion of safe place management and make a defined contribution the paper has reported on the use and intervention of a crowd assessment safety risk model, the "DIM-ICE risk model". The aim of the study was to report on the impact and use of this intervention on place crowd safety and the application of crowd science. In addition, we offer the following learning points for practitioners, drawing upon the significant background provided by the presented cases.

\subsection{What do we learn from the application of the design, information, management-ingress, circulation, egress model?}

The model was developed from the analysis of past disasters and their fundamental causes. So the model helps users consider the phases and influences of crowd behaviour through the lens/filter of causality. In essence, it draws the attention of the user to think through the event in time (ICE) and controls (DIM). In response to these issues, the DIM-ICE risk model was used to compare operational situations during so-called "normal" and then "emergency" conditions for each phase 
Figure 5.

The DIM-ICE risk model - the Murrayfield Stadium project

\begin{tabular}{|c|c|c|c|}
\hline NORMAL & Ingress & Circulation & Egress \\
\hline & $\begin{array}{l}\text { Limited entry } \\
\text { capacity: } \\
\text { queuing/congestion }\end{array}$ & $\begin{array}{l}\text { Overcrowding / } \\
\text { congested spaces } \\
\text { west end area }\end{array}$ & $\begin{array}{l}\text { Limited exit } \\
\text { capacity of the west } \\
\text { end area }\end{array}$ \\
\hline Design & $\begin{array}{l}\text { The impact of the } \\
\text { physical change on } \\
\text { site upon } \\
\text { merchandising } \\
\text { locations was known }\end{array}$ & $\begin{array}{l}\text { The impact of the } \\
\text { physical change on } \\
\text { site upon } \\
\text { merchandising } \\
\text { locations was } \\
\text { known }\end{array}$ & $\begin{array}{l}\text { The impact of the } \\
\text { physical change on } \\
\text { site upon } \\
\text { merchandising } \\
\text { locations was } \\
\text { known }\end{array}$ \\
\hline Information & $\begin{array}{l}\text { Unclear signage for } \\
\text { arriving visitors } \\
\text { approaching the } \\
\text { stadium }\end{array}$ & $\begin{array}{l}\text { Unclear signage for } \\
\text { visitors being in the } \\
\text { stadium }\end{array}$ & $\begin{array}{l}\text { Unclear signage for } \\
\text { visitors exiting the } \\
\text { stadium }\end{array}$ \\
\hline \multirow[t]{2}{*}{ Management } & $\begin{array}{l}\text { Limited } \\
\text { communication } \\
\text { between the } \\
\text { operations team and } \\
\text { the building } \\
\text { construction } \\
\text { engineers; the impact } \\
\text { of the physical } \\
\text { change on site upon } \\
\text { merchandising } \\
\text { locations was known }\end{array}$ & $\begin{array}{l}\text { Limited } \\
\text { communication } \\
\text { between the } \\
\text { operations team and } \\
\text { the building } \\
\text { construction } \\
\text { engineers; the } \\
\text { impact of the } \\
\text { physical change on } \\
\text { site upon } \\
\text { merchandising } \\
\text { locations was } \\
\text { known }\end{array}$ & $\begin{array}{l}\text { Limited } \\
\text { communication } \\
\text { between the } \\
\text { operations team and } \\
\text { the building } \\
\text { construction } \\
\text { engineers; the } \\
\text { impact of the } \\
\text { physical change on } \\
\text { site upon } \\
\text { merchandising } \\
\text { locations was } \\
\text { known }\end{array}$ \\
\hline & $\begin{array}{l}\text { The risk assessment } \\
\text { processes required to } \\
\text { be updated }\end{array}$ & $\begin{array}{l}\text { The risk assessment } \\
\text { processes required } \\
\text { to be updated }\end{array}$ & $\begin{array}{l}\text { The risk assessment } \\
\text { processes required } \\
\text { to be updated }\end{array}$ \\
\hline EMERGENCY & Ingress & Circulation & Egress \\
\hline Design & $\begin{array}{l}\text { Limited flow } \\
\text { capacity (narrow } \\
\text { footpaths) }\end{array}$ & $\begin{array}{l}\text { Overcrowding / } \\
\text { congested spaces } \\
\text { west end area }\end{array}$ & $\begin{array}{l}\text { Limited exit } \\
\text { capacity of the west } \\
\text { end area }\end{array}$ \\
\hline Information & $\begin{array}{l}\text { Unclear signage for } \\
\text { arriving visitors } \\
\text { approaching the } \\
\text { stadium }\end{array}$ & $\begin{array}{l}\text { Unclear signage for } \\
\text { visitors being in the } \\
\text { stadium }\end{array}$ & $\begin{array}{l}\text { Unclear signage for } \\
\text { visitors exiting the } \\
\text { stadium }\end{array}$ \\
\hline Management & $\begin{array}{l}\text { The updated risk } \\
\text { assessment processes } \\
\text { are missing }\end{array}$ & $\begin{array}{l}\text { The updated risk } \\
\text { assessment } \\
\text { processes are } \\
\text { missing }\end{array}$ & $\begin{array}{l}\text { The updated risk } \\
\text { assessment } \\
\text { processes are } \\
\text { missing }\end{array}$ \\
\hline
\end{tabular}

Note: White squares $=$ areas that are sufficient, no improvements are required; Light grey squares = require improvement; and Grey squares = require much improvement to avoid crowd safety issues

and aspect of proceedings to fully scope out crowd dynamics at an event. Helbing et al. (2007) clearly state that that pure mathematical approaches and analytic models are not adequate for this purpose, that the conventional risk assessment process is mathematically biased.

\subsection{What works, in what contexts?}

It works because the user has to put some description and colour code each of the 18 boxes. A gap/space on the matrix means a gap in their knowledge - which then needs to be filled. For clarification and enhanced communication, we recommend the use of red/amber/green colour coding in the DIM-ICE matrix to highlight areas that are as follows:

- well organised (green);

- those that require improvement or monitoring during an event (amber); and

- those that must be improved (red). 
Haase et al. (2019) reported on overcrowding being a frequent cause of crowd disasters, this highly visual method serves to clearly pinpoint where and potentially when this might occur. When applied and facilitated by an informed cross-discipline operational team the approach allows the potential rapid identification of high-risk areas. Alternative place design, communication and management requirements can then be identified, discussed, considered and implemented to allow the development and adoption of appropriate operational strategies on site. This goes beyond the rather rudimentary aspects outlined in the available literature by Helbing et al. (2000), Helbing et al. (2005), Kretz et al. (2006), Georgoudas et al. (2010) and Shahhoseini et al. (2018), e.g. lane formation, oscillations at bottlenecks, the faster-is-slower effect and so-called "clogging" at exits. This contribution is important as Haase et al. (2019) described the number and severity of fatal crowd disasters in high-density public events rising significantly.

As per Duives et al. (2013), adequate crowd movement information (facilities, locations, correct exits in an emergency, etc.) must be clearly communicated to the attendees/public in a manner that removes any scope for ambiguity. The DIM-ICE risk model, therefore, has the potential to provide an evidence-based comprehensive pre-event analysis, which properly forecasts potential crowd issues ensuring a successful event, where the attendees enjoy a positive experience (AlZaydi et al., 2016). Upton (2008) suggested that successful planning of an event requires an indepth risk assessment of crowd safety, which the reported intervention of the DIM-ICE risk model achieves. The DIM-ICE risk model can be used across the spectrum - to show green/amber/red in context and as a methodology for systematic and rigorous assessment of the risks using phases of behaviour and influences on behaviour through the design of the place, information and management. In essence, it provides a "how to shape the crowds' behaviour" guide.

\subsection{What does not work?}

The DIM-ICE risk model is risk/causality-based. It does not define routing-area-movementpeople. However, when used with other tools and knowledge it is a comprehensive risk-based analysis method. The implementation of the model assists event planners to identify locations and potentially times of high risk and control them, through effective place design, information systems and management strategies. Still (2015a, 2015b) suggested that this model provides solutions to complex safety issues by simplifying them into elements for consideration, a multiscale approach to the overall process of event planning (zoom into a section, then zoom out to see the overall impact on the event), providing the information required for the planning phase. It sits between the traditional approaches of crowd modelling, considered under macroscopic (treat the crowd system as a whole) and microscopic (smaller crowds, real-time simulation, individual behaviour and interactions) scales (Xu et al., 2014; Bellomo et al., 2016) and the impressive but resource-intensive virtual environment representations (Yersin et al., 2005; Yersin et al., 2009). In a similar manner to the above, the application of the DIM-ICE risk model is required prior to an event to establish a crowd risk plan; for example, ingress and egress routes have to be of sufficient size to safely accommodate predicted crowds, therefore, avoiding congestion that may occur. However, it is the robustness and relevance of its application that appears to make a difference (Still, 2014a, 2014b) creating a much-needed evidence base (Helbing et al., 2007) to inform operational decision making.

\subsection{What limitations this model presents?}

It is only one of a number of tools that can/should be used regards safety in place management. Together they cover the risk dynamics. So it is part of a suite of tools - specific to each place. The case studies presented within this paper seek to inform the challenges and limitations of crowded environments that event organisers face, as highlighted by Hou and Pang (2010). The paper provides information regarding the application of an evidence-based 
approach (the DIM-ICE risk model), addressing the research gap related to the implementation of analytic tools in characterising crowd dynamics identified by Helbing et al. (2007). It contributes to what Chai et al. (2017) identified as the emerging field of research motivated by crowd safety issues in our increasingly congested environments. It also provides further understanding to place management terms as "improved knowledge and more effective place management practice can ultimately lead to places that are more successful, more liveable and more equitable" (Kalandides et al., 2016, p. 358).

To take this development further we suggest more research into aspects of crowd safety, crowd science and its application. Ultimately this goes beyond simple reporting and has the very great potential to make a defined and measurable impact, not just to specific crowd events but also to society as a whole.

\section{References}

Al Jazeera (2019) Thousands stage global climate protests before UN summit, Al Jazeera and News Agencies, available at: https://aljazeera.com/news/2019/11/thousands-stage-global-climateprotests-summit-191129140130762.htm

Al-Zaydi, Z.Q., Ndzi, D.L., Yang, Y. and Kamarudin, M.L. (2016), “An adaptive people counting system with dynamic features selection and occlusion handling", Journal of Visual Communication and Image Representation, Vol. 39, pp. 218-225.

Badiora, A.I. and Odufuwa, B.O. (2019), "Fear dynamics in public places: a case study of urban shopping centers", Journal of Place Management and Development, Vol. 12 No. 2, pp. 248-270.

Bandini, S., Federici, M.L. and Vizzari, G. (2007), "Situated cellular agents approach to crowd modeling and simulation", Cybernetics and Systems, Vol. 38 No. 7, pp. 729-753.

Bell, E., Bryman, A. and Harley, B. (2018), Business Research Methods, Oxford University Press, Oxford.

Bellomo, N., Clarke, D., Gibelli, L., Townsend, P. and Vreugdenhil, B. (2016), "Human behaviours in evacuation crowd dynamics: from modelling to "big data" toward crisis management", Physics of Life Reviews, Vol. 18, pp. 1-21.

Berlonghi, A.E. (1995), "Understanding and planning for different spectator crowds", Safety Science, Vol. 18 No. 4, pp. 239-247.

Birch, P. Young, R. and Chatwin, C. (2017), "Smart cameras? II".

Chai, Y., Miao, C., Sun, B., Zheng, Y. and Li, Q. (2017), "Crowd science and engineering: concept and research framework", International Journal of Crowd Science, Vol. 1 No. 1, pp. 2-8.

Daamen, W. and Hoogendoorn, S.P. (2003), "Experimental research of pedestrian walking behavior", Transportation Research Record: Journal of the Transportation Research Board, Vol. 1828 No. 1, pp. 20-30.

Di Domenico, S., Pecoraro, G., Cianca, E. and De Sanctis, M. (2016), "Trained-once device-free crowd counting and occupancy estimation using wifi: a doppler spectrum based approached", IEEE 12th International Conference on Wireless and Mobile Computing, Networking and Communications (WiMob), IEEE, pp. 1-8.

Dos Reis, J.V.D. (2014), “Image descriptors for counting people with uncalibrated cameras".

Duives, D.C., Daamen, W. and Hoogendoorn, S.P. (2013), "State-of-the-art crowd motion simulation models”, Transportation Research Part C: Emerging Technologies, Vol. 37, pp. 193-209.

Fruin, J. (1984), "Crowd dynamics and auditorium management. In an international association of auditorium managers", Auditorium News, available at: www.gkstill.com/Support/crowd-flow/ fruin/Fruin3.html

Fruin, J.J. (2002), "The causes and prevention of crowd disasters", 20 January, available at: www. crowdsafe.com/fruincauses.pdf 
Georgoudas, I.G., Sirakoulis, G.C. and Andreadis, I.T. (2010), "An anticipative crowd management system preventing clogging in exits during pedestrian evacuation processes", IEEE Systems Journal, Vol. 5 No. 1, pp. 129-141.

GSSG (2008) Guide to Safety at Sports Grounds, Fifth Edition, Department for Culture, Media and Sport, Her Majesty's Stationery Office.

Haase, K., Kasper, M., Koch, M. and Müller, S. (2019), "A pilgrim scheduling approach to increase safety during the Hajj”, Operations Research, Vol. 67 No. 2, pp. 376-406.

Haghani, M. and Sarvi, M. (2018), "Crowd behaviour and motion: empirical methods", Transportation Research Part B: Methodological, Vol. 107, pp. 253-294.

Health and Safety Executive [HSE] (1997), "Fairgrounds and amusement parks: guidance on safe practice", HSE Publication HS(G) 175.

Health and Safety Executive [HSE] (1998), Guide to Fire Precautions in Existing Places of Entertainment and like Premises, HMSO London.

Health and Safety Executive [HSE] (1999), "The event safety guide: a guide to health", Safety and Welfare at Music and Similar Events, 2nd ed. Surrey: HSE Books.

Helbing, D., Farkas, I. and Vicsek, T. (2000), "Simulating dynamical features of escape panic", Nature, Vol. 407 No. 6803, pp. 487.

Helbing, D., Johansson, A. and Al-Abideen, H.Z. (2007), "Dynamics of crowd disasters: an empirical study", Physical Review E, Vol. 75 No. 4, pp. 046109.

Helbing, D., Buzna, L., Johansson, A. and Werner, T. (2005), "Self-organized pedestrian crowd dynamics: experiments, simulations, and design solutions", Transportation Science, Vol. 39 No. 1, pp. 1-24.

Hou, Y.L. and Pang, G.K. (2010), "People counting and human detection in a challenging situation", IEEE Transactions on Systems, Man, and Cybernetics-Part A: Systems and Humans, Vol. 41 No. 1, pp. 24-33.

Ibem, E.O., Uwakonye, O. and Aduwo, E.B. (2013), "An appraisal of urban renewal in Nigeria a case study of the Nigerian army shopping Arena, Oshodi-Lagos", Journal of Place Management and Development, Vol. 6 No. 2, pp. 155-170.

Kalandides, A., Millington, S., Parker, C. and Quin, S. (2016), "Shopping districts and centres, markets, neighbourhoods, public squares, and urban gardens reflecting upon place management practice in Berlin", Journal of Place Management and Development, Vol. 9 No. 3, pp. 351-359.

Kretz, T., Wolki, M. and Schreckenberg, M. (2006), "Characterizing correlations of flow oscillations at bottlenecks", Journal of Statistical Mechanics: Theory and Experiment, Vol. 2006 No No. 02 , p. P02005.

Lak, A., Ramezani, M. and Aghamolaei, R. (2019), "Reviving the lost spaces under urban highways and bridges: an empirical study”, Journal of Place Management and Development, Vol. 12 No. 4, p. 469.

Lev, L. Brewer, L.J. and Stephenson, G.O. (2008), "Tools for rapid market assessments”,

Mullin, J. Campbell, D. Wintour, P. Sharrock, D. Chauchary, V. Pallister, D. and Nowicka, H. (1996), "IRA smash ceasefire", The Guardian, Sat 10 Feb 1996 (retrieved 26/09/19).

Parker, C. (2008), "Extended editorial: place - the trial frontier", Journal of Place Management and Development, Vol. 1 No. 1, pp. 5-14.

Pasquinelli, C., Koukoufikis, G. and Gogishvili, D. (2018), "Beyond eventification: capacity building in postdisaster temporariness", Journal of Place Management and Development, Vol. 12 No. 1, pp. 88-101.

Shahhoseini, Z., Sarvi, M. and Saberi, M. (2018), "Pedestrian crowd dynamics in merging sections: Revisiting the "faster-is-slower" phenomenon", Physica A: Statistical Mechanics and Its Applications, Vol. 491, pp. 101-111.

Shannon, C.E. (1948), "A mathematical theory of communication”, Bell System Technical Journal, Vol. 27 No. 3, pp. 379-423.623-656, July, October.

Sime, J.D. (1993), “Crowd psychology and engineering: designing for people or ballbearings?”, in Smith, R.S. and Dickie, J.F. (Eds), Engineering for Crowd Safety, Elsevier Science Publishers: BV. 
Smith, K. (2003), Environmental Hazards: assessing Risk and Reducing Disaster, Routledge.

Still, G.K. (2000), Crowd Dynamics, University of Warwick.

Still, K. (2009), "Safety in numbers", ISquared, Summer, pp. 23-26.

Still, G.K. (2011), "Standing crowd density", available at: www.gkstill.com/Support/crowd-density/ CrowdDensity-1.html

Still, G.K. (2014a), Introduction to Crowd Science, CRC Press.

Still, K. (2014b), "Visualising risk assessment for crowd safety", Journal of the International Centre for Sports Security, Vol. 2 No. 1, available at: http://icss-journal.newsdeskmedia.com/images/ Upload/Vol_2_n0_1/ICSS_Vol2.1.pdf

Still, K. (2015a), "Fruin - levels of service", available at: www.gkstill.com/Support/crowd-flow/fruin/ Fruin1.html

Still, K. (2015b), Crowd Science and Risk Analysis. In Level 5 Diploma in Crowd Science, 25-27 May 2015, Brisbane.

Still, G.K. (2019), “Crowd science and crowd counting”, Impact, Vol. 2019 No. 1, pp. 19-23.

Upton, M. (2004), "Risk analysis for major concert events, the benefits of hindsighted", Cabinet Office Seminar on Safety at Mass Crowd Events (January 2004).

Upton, M. (2008), "Safe event management", Paper delivered to the Theatre Managers Association Conference, Birmingham, 10 June 2008.

Xu, M.L., Jiang, H., Jin, X.G. and Deng, Z. (2014), "Crowd simulation and its applications: recent advances", Journal of Computer Science and Technology, Vol. 29 No. 5, pp. 799-811.

Yersin, B., Maïm, J., Pettré, J. and Thalmann, D. (2009), "Crowd patches: populating large-scale virtual environments for real-time applicationsed", Proceedings of the 2009 symposium on Interactive 3D graphics and games, ACM, pp. 207-214.

Yersin, B., Maïm, J., Ciechomski, P., Schertenleib, S. and Thalmann, D. (2005), "Steering a virtual crowd based on a semantically augmented navigation graphed", Proc. The First International Workshop on Crowd Simulation (V-CROWDS’05), Lausanne, Switzerland, pp. 169-178.

Yin, R.K. (2018), Case Study Research and Applications, SAGE Publications London.

Yuan, Y., Qiu, C., Xi, W. and Zhao, J. (2011), "Crowd density estimation using wireless sensor networksed”, Seventh international conference on mobile Ad-hoc and sensor networks, IEEE, 138-145.

\section{Further readings}

Sports Grounds Safety Authority (2008), Guide to Safety at Sports Ground (the Green Guide), 5th ed., TSO, London.

Li, J., Huang, L. and Liu, C. (2011), "Robust people counting in video surveillance: dataset and system", 8th IEEE International Conference on Advanced Video and Signal Based Surveillance (AVSS), Klagenfurt, pp. 54-59.

\section{Corresponding author}

David Bamford can be contacted at: d.bamford@mmu.ac.uk

For instructions on how to order reprints of this article, please visit our website: 